\title{
Mandelic Acid
}

National Cancer Institute

\section{Source}

National Cancer Institute. Mandelic Acid. NCI Thesaurus. Code C61822.

An aromatic alpha hydroxy acid used in the treatment of urinary tract infections and as an oral antibiotic. 